\begin{tabular}{|l|l|l||}
\hline \multicolumn{2}{|c|}{ PublisherInfo } \\
\hline \hline PublisherName & $:$ & BioMed Central \\
\hline \hline PublisherLocation & $:$ & London \\
\hline \hline PublisherImprintName & $:$ & BioMed Central \\
\hline \hline
\end{tabular}

\title{
IgA anti-?2-glycoprotein I antibodies
}

\begin{tabular}{|l|l|l||}
\hline \multicolumn{2}{|c||}{ ArticleInfo } \\
\hline \hline ArticleID & $:$ & 233 \\
\hline \hline ArticleDOI & $:$ & $10.1186 /$ ar-1999-66741 \\
\hline \hline ArticleCitationID & $:$ & 66741 \\
\hline \hline ArticleSequenceNumber & $:$ & 190 \\
\hline \hline ArticleCategory & $:$ & Paper Report \\
\hline \hline ArticleFirstPage & $:$ & 1 \\
\hline \hline ArticleLastPage & $:$ & 1 \\
\hline \hline & & RegistrationDate : 1999-11-3 \\
\hline ArticleHistory & $:$ & OnlineDate \\
\hline \hline ArticleCopyright & $:$ & Current Science Ltd1999-11-3 \\
\hline \hline ArticleGrants & $:$ & \\
\hline \hline ArticleContext & $:$ & 130753311 \\
\hline \hline
\end{tabular}


Aff1 Royal Free and University College School of Medicine, USA

\section{Keywords}

Anti-cardiolipin, anti phospholipid antibody syndrome, ?2-glycoprotein I

\section{Context}

The anti phospholipid syndrome (APS) is characterised by clinical manifestations of thromboembolic phenomena, intra-uterine fetal loss and thrombocytopenia. APS is also associated with anti-phospholipid antibodies, which are autoantibodies directed against a modified ?2-glycoprotein I (?2-GPI). The modified structure is a result of interaction with anionic phospholipids. Although IgG, and to some extent IgM anti phospholipid antibodies are recognised as being of diagnostic significance, the role of IgA autoantibodies is not clear. This study examined the role of IgG, IgM and IgA isotype anti-? 2-GPI in APS. To evaluate the prevalance of IgG, IgA and IgM anti-?2-GPI antibodies in APS, and to establish the clinical significance of IgA type antibodies compared with other isotypes.

\section{Significant findings}

As expected, anti-?2-GPI antibodies were detected at higher titre in patients with APS than normal controls. Subgroup analysis showed that APS patients with high IgG anti-?2-GPI titres were associated with venous thrombosis $(P=0.003)$, thrombocytopenia $(P=0.01)$, fetal loss $(P=0.01)$ or heart valve disease $(P<0.03)$. High IgM anti-?2-GPI was associated with only thrombocytopenia $(P<0.04)$ or heart valve disease $(P=0.01)$. Elevated IgA anti-?2-GPI titres were linked to venous thrombosis $(P=$ 0.007), thrombocytopenia $(P<0.02)$, or heart valve disease $(P<0.02)$ (all also associated with other isotypes) and also livido reticularis $(P=0.01)$ or epilepsy $(P=0.01)$ (IgA isotype only).

\section{Comments}

The increased specificity of anti-? 2-GPI antibodies makes them an attractive tool in the diagnosis of APS. This study provides an interesting observation that IgA isotype antibodies may be associated with 
subsets of APS syndrome, which would be missed using tests for IgG and IgM isotypes only.

Unfortunately, only three primary APS patients were assessed, so for the moment this association can only really be claimed for APS secondary to SLE. In addition, it appears that patients with IgG anticardiolipin were positively selected for, so the association with IgA anti-? 2-GPI may be stronger in unselected populations. The authors took the wise precaution of exluding patients with IgA deficiency from their study, this step would also be important for diagnosis in clinical practice.

\section{Methods}

30 patients with symptoms of APS secondary to systemic lupus erythematosus (SLE), three patients with primary APS and 30 normal controls had anti-cardiolipin and anti-?2-GPI antibodies measured by ELISA.

\section{References}

1. Lakos G, Kiss E, Regeczy N: Isotype distribution and clinical relevance of anti-?2-glycoprotein I (?2GPI) antibodies: importance of IgA isotype. Clin Exp Immunol. 1999, 117: 574-579.

This PDF file was created after publication. 